\title{
Analisis Pengaruh Pengajaran dan Sertifikasi Guru terhadap Kompetensi Guru pada Sekolah Menengah Kejuruan Di Wilayah Parung Panjang Kabupaten Bogor
}

\section{Analysis of the Effect of Teaching and Teacher Certification on Teacher Competence at Vocational High Schools in the Parung Panjang Area, Bogor Regency}

\author{
Akhmar Barsah, Aden Prawiro Sudarso \& Denok Sunarsi \\ Universitas Pamulang, Banten, Indonesia
}

Diterima: 03 Oktober 2020; Direview: 03 Oktober 2020; Disetujui: 18 Oktober 2020

*Coresponding Email : dosen01578@unpam.ac.id1 dosen01171@unpam.ac.id² denoksunarsi@unpam.ac.id 3

\section{Abstrak}

Penelitian ini bertujuan untuk mengetahui pengaruh pengajaran berbasis teknologi informasi dan sertifikasi guru terhadap kompetensi guru serta implikasinya pada kinerja guru pada Sekolah Menengah Kejuruan di Wilayah Parung Panjang Kabupaten Bogor, Jawa Barat. Metode yang digunakan adalah explanatory research dengan teknik analisis menggunakan analisis statistik dengan pengujian regresi, determinasi dan uji hipotesis.Hasil penelitian ini pengajaran berbasis teknologi informasi berpengaruh signifikan terhadap kompetensi guru dengan diperoleh uji hipotesis thitung $>t$ tabel $(3,978>1,980)$. Sertifikasi guru berpengaruh signifikan terhadap kompetensi guru dengan diperoleh uji hipotesis thitung $>\mathrm{t}$ tabel $(4,449>1,980)$. Pengajaran berbasis teknologi informasi dan sertifikasi guru secara simultan berpengaruh signifikan terhadap kompetensi guru dengan diperoleh uji hipotesis $\mathrm{F}$ hitung $>\mathrm{F}$ tabel $(19,213>3,080)$. Pengajaran berbasis teknologi informasi berpengaruh signifikan terhadap kinerja guru dengan diperoleh uji hipotesis $t$ hitung $>t$ tabel $(3,030>1,980)$. Sertifikasi guru berpengaruh signifikan terhadap kinerja guru dengan diperoleh uji hipotesis t hitung $>\mathrm{t}$ tabel $(2,870>1,980)$. Kompetensi guru berpengaruh signifikan terhadap kinerja guru dengan diperoleh uji hipotesis t hitung $>\operatorname{tabel}(3,747>1,980)$. Pengajaran berbasis teknologi informasi, sertifikasi guru dan kompetensi guru secara simultan berpengaruh signifikan terhadap kinerja guru dengan diperoleh uji hipotesis $\mathrm{F}$ hitung $>\mathrm{F}$ tabel $(20,238>2,680)$.

Kata Kunci: Pengajaran Berbasis Teknologi Informasi, Sertifikasi Guru, Kompetensi Guru, Kinerja Guru

\begin{abstract}
This study aims to determine the effect of information technology-based teaching and teacher certification on teacher competence and its implications for teacher performance at Vocational High Schools in Parung Panjang, Bogor Regency, West Java. The method used is explanatory research with analysis techniques using statistical analysis with regression testing, determination and hypothesis testing. The results of this research that information technology-based teaching has a significant effect on teacher competence by obtaining the hypothesis test $t$ count $>t$ table $(3.978>1.980)$. Teacher certification has a significant effect on teacher competence by obtaining the hypothesis test $t$ count $t$ table (4.449> 1.980). Information technology-based teaching and teacher certification simultaneously have a significant effect on teacher competence by obtaining the hypothesis test $F$ count $>$ F table $(19,213>3,080)$. Information technology-based teaching has a significant effect on teacher performance by obtaining the hypothesis test $t$ count $>t$ table $(3.030>1.980)$. Teacher certification has a significant effect on teacher performance by obtaining the hypothesis test $t$ count $>t$ table (2.870> 1.980). Teacher competence has a significant effect on teacher performance by obtaining the hypothesis test $t$ count $>t$ table $(3,747>1,980)$. Information technology-based teaching, teacher certification and teacher competence simultaneously have a significant effect on teacher performance by obtaining the hypothesis test $F$ count $>$ F table $(20,238>2,680)$.
\end{abstract}

Keywords: Information Technology Based Teaching, Teacher Certification, Teacher Competence, Teacher Performance

How to Cite: Barsah, A. Sudarso, A.P. \& Sunarsi, D. (2020). Analisis Pengaruh Pengajaran Berbasis Teknologi Informasi Dan Sertifikasi Guru Terhadap Kompetensi Guru Serta Implikasinya Pada Kinerja Guru Pada Sekolah Menengah Kejuruan Di Wilayah Parung Panjang Kabupaten Bogor, Jawa Barat. Journal of Education, Humaniora and Social Sciences (JEHSS). 3(2): 650-657. 


\section{PENDAHULUAN}

Dunia pendidikan saat ini mulai mengintegrasikan teknologi pada berbagai aspek termasuk dalam pembelajaran. Kebijakan pendidikan diarahkan untuk memanfaatkan teknologi informasi dan komunikasi sehingga mampu mempersiapkan sumber daya manusia yang mampu menghadapi tantangan global. Dengan memanfaatkan perkembangan teknologi informasi dan komunikasi, pendidikan dapat menjangkau seluruh lapisan masyarakat yang tinggal diberbagai tempat, di kota, desa, bahkan di daerah terpencil atau pedalaman, salah satu lembaga pendidikan adalah sekolah. Sekolah merupakan suatu wadah untuk menciptakan manusia yang berpendidikan tanpa melihat latar belakang dari peserta didik tersebut (Manurung \& Lahmuddin, 2010; Fadilah et al., 2020; Simorangkir et al., 2014). Sekolah diharapkan mampu menciptakan output yang optimal yaitu sumber daya manusia (SDM) yang mampu bersaing di dunia global. Untuk mewujudkannya maka dalam pelaksanaan pembelajaran memanfaatkan teknologi informasi dan komunikasi karena di dunia Internasional perkembangan teknologi semakin pesat(Cahyono et al., n.d.).

Berbicara mengenai kualitas pendidikan maka tak akan lepas dari peningkatan kompetensi dan profesionalitas guru. Guru merupakan unsur utama dalam keseluruhan proses pendidikan dan di setiap jenjang pendidikan, khususnya ditingkat institusional dan instruksional. Guru merupakan sosok yang mengemban tanggung jawab untuk mewujudkan tujuan pendidikan nasional seperti yang telah dijelaskan dalam UU No. 20 Tahun 2003 tentang SISDIKNAS bahwa: Pendidikan Nasional berfungsi mengembangkan kemampuan dan membentuk watak serta peradaban bangsa yang bermartabat dalam rangka mencerdaskan kehidupan bangsa, bertujuan untuk berkembangnya potensi peserta didik agar menjadi manusia yang beriman, bertaqwa Kepada Tuhan Yang Maha Esa, berakhlak mulia, sehat, berilmu, cakap, kreatif, mandiri, dan menjadi warga negara yang demokratis serta bertanggung jawab (Indrawan, Wijoyo, Suherman, et al., 2020).

Sertifikasi guru merupakan salah satu cara dalam dunia pendidikan untuk meningkatkan kualitas dan profesionalitas guru, sehingga ke depan semua guru harus memiliki sertifikat sebagai lisensi atau ijin mengajar (Wijoyo \& Indrawan, 2020). Dengan demikian, upaya pembentukan guru yang profesional di Indonesia segera menjadi kenyataan seperti yang diharapkan. Semakin meningkat kualitas dan profesionalitas guru, semakin baik pula kualitas negara tersebut. Itulah asumsi secara umum terhadap program pendidikan suatu negara. Pendidikan merupakan suatu upaya mencerdaskan kehidupan bangsa dan meningkatkan harkat dan martabat manusia melalui pendidikan diharapkan dapat tercapai peningkatan kehidupan manusia kearah yang lebih sempurna (Gaol \& Azhar, 2013; Mukhadis \& Isnandar, 2012; Juniarti \& Sukartini, 2014; Akbar, 2018). Pelaksanaan program pendidikan didukung dengan kepemimpinan yang demokratis dan profesional, guru yang profesional dan memiliki kompetensi dalam bidangnya masing-masing, serta tenaga administrasi professional dalam pengelolaan administrasi Pendidikan (Indrawan, Wijoyo, Astuti, et al., 2020).

Dalam hal ini, guru tidak semata-mata sebagai pengajar yang melakukan transfer ilmu pengetahuan kepada siswanya, tetapi guru juga sebagai pendidik yang melakukan transfer nilainilai sekaligus sebagai pembimbing yang memberikan pengarahan dan menuntun semua siswa dalam belajar (Hasmayani \& Hotman, 2012; Siregar \& Sri, 2012; Milfayetty, 2009). Guru adalah modal utama di dalam bidang pendidikan. Guru sebagai modal utama dalam bidang pendidikan mempunyai pikiran, perasaan, status, keinginan dan latar belakang yang heterogen (Wijoyo et al., 2020). Kinerja guru sangat ditentukan oleh kompetensi guru itu sendiri dan salah satu syarat mendapatkan sertifikasi guru adalah dengan kompetensi yang mumpuni serta penguasaan kurikulum yang baik yang dituangkan dalam pengajaran yang baik dan komprehensif, berdasarkan pemaparan diatas, maka penulis tertarik meneliti dengan judul Analisis Pengaruh Pengajaran Berbasis Teknologi Informasi Dan Sertifikasi Guru Terhadap Kompetensi Guru Serta Implikasinya Pada Kinerja Guru Studi Pada Sekolah Menengah Kejuruan Di Wilayah Parung Panjang. Kabupaten Bogor. Jawa Barat. 


\section{METODE PENELITIAN}

Populasi dalam penelitian ini berjumlah 165 responden yaitu guru Sekolah Menengah Kejuruan di Wilayah Parung Panjang Kabupaten Bogor, Jawa Barat. Sampel dalam penelitian ini dicari dengan menggunakan rumus Slovin dengan tingkat error 0,05 dan diperoleh sampel sebanyak 117 responden. Jenis penelitian yang dipakai adalah asosiatif, dimana tujuannya adalah untuk mengetahui pengaruh antara variabel bebas terhadap variabel terikat baik parsial maupun simultan. Dalam menganalisis data digunakan uji instrumen, uji asumsi klasik, regresi, koefisien determinasi dan uji hipotesis.

\section{HASIL DAN PEMBAHASAN}

\section{Analisis Deskriptif}

Pada pengujian ini digunakan untuk mengetahui skor minimum dan maksimum, mean score dan standar deviasi dari masing-masing variabel. Adapun hasilnya sebagai berikut:

Tabel 1. Hasil Analisis Descriptive Statistics

\begin{tabular}{llll}
\hline Variabel & Mean Score & Interval & Keterangan \\
\hline PBTI & 3,96 & $3,40-4,19$ & Baik \\
\hline Sertifikasi Guru (X2) & 4,05 & $3,40-4,19$ & Baik \\
\hline Kompetensi Guru (Y) & 4,06 & $3,40-4,19$ & Baik \\
\hline Kinerja Guru (Z) & 4,28 & $4,20-5,00$ & Sangat Baik \\
\hline
\end{tabular}

Hasil analisis deskriptif dari tabulasi distribusi jawaban responden untuk keseluruhan variabel penelitian dapat diambil kesimpulan bahwa variabel PBTI (X1) didapat nilai rata-rata 3.96 dengan kriteria baik dimana nilai tersebut berada pada interval 3,40-4,19.

Hasil analisis deskriptif dari tabulasi distribusi jawaban responden untuk keseluruhan variabel penelitian dapat diambil kesimpulan bahwa variabel sertifikasi guru (X2) didapat nilai rata-rata 4.05 dengan kriteria baik dimana nilai tersebut berada pada interval 3,40-4,19.

Hasil analisis deskriptif dari tabulasi distribusi jawaban responden untuk keseluruhan variabel penelitian dapat diambil kesimpulan bahwa variabel kompetensi guru $(Y)$ didapat nilai rata-rata 4.06 dengan kriteria baik dimana nilai tersebut berada pada interval 3,40-4,19.

Hasil analisis deskriptif dari tabulasi distribusi jawaban responden untuk keseluruhan variabel penelitian dapat diambil kesimpulan bahwa variabel kinerja guru (Z) didapat nilai ratarata 4.28 dengan kriteria sangat baik dimana nilai tersebut berada pada interval 4,20-5,00.

\section{Analisis Jalur (Path Analisis) Sub-Struktur I.}

Pada analisis ini dimaksudkan untuk mengetahui pengaruh variabel independen terhadap variabel dependen. Adapun hasil pengujian sebagai berikut:

\section{a. Uji Simultan (Uji F)}

Pada uji hipotesis ini dimaksudkan untuk mengetahui pengaruh secara simultan antara Pengajaran berbasis teknologi informasi dan sertifikasi guru terhadap kompetensi guru.. Adapun hasil pengujiannya sebagai berikut:

Tabel 2. Hasil Pengujian Hipotesis (Uji F)

\begin{tabular}{llllllll}
\multicolumn{2}{l}{$\begin{array}{l}\text { ANOVA } \\
\text { Model }\end{array}$} & Sum of Squares & df & Mean Square & F & Sig. \\
\hline \multirow{2}{*}{1} & Regression & 919.852 & 2 & 459.926 & 19.213 & .0oo $^{\text {b }}$ \\
\cline { 2 - 8 } & Residual & 2728.957 & 114 & 23.938 & & \\
\cline { 2 - 8 } & Total & 3648.809 & 116 & & & \\
\hline
\end{tabular}

a. Dependent Variable: Kompetensi Guru

b. Predictors: (Constant), Sertifikasi Guru, PBTI

Berdasarkan hasil pengujian pada tabel di atas, diperoleh nilai $\mathrm{F}$ hitung $>\mathrm{F}$ tabel atau $(19,213$ $>3,080$ ), dan ini diperkuat dengan signifikansi $0,000<0,05$. Dengan demikian hipotesis yang diajukan bahwa terdapat pengaruh yang signifikan antara pengajaran berbasis teknologi informasi dan sertifikasi guru terhadap kompetensi guru diterima.

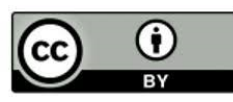




\section{b. Uji Parsial (Uji t)}

Pada uji hipotesis ini dimaksudkan untuk mengetahui pengaruh secara parsial antara Pengajaran berbasis teknologi informasi dan sertifikasi guru terhadap kompetensi guru.. Adapun hasil pengujiannya sebagai berikut:

$$
\begin{gathered}
\text { Tabel 3. Hasil Pengujian Hipotesis (Uji t) } \\
\text { Coefficients }^{\mathrm{a}}
\end{gathered}
$$

\begin{tabular}{|c|c|c|c|c|c|c|}
\hline \multirow{2}{*}{\multicolumn{2}{|c|}{ Model }} & \multicolumn{2}{|c|}{ Unstandardized Coefficients } & \multirow{2}{*}{$\begin{array}{l}\text { Standardized Coefficients } \\
\text { Beta }\end{array}$} & \multirow[b]{2}{*}{$\mathrm{t}$} & \multirow[b]{2}{*}{ Sig. } \\
\hline & & B & Std. Error & & & \\
\hline 1 & (Constant) & 10.318 & 3.816 & & 2.704 & .008 \\
\hline & PBTI & .323 & .081 & .323 & 3.978 & .000 \\
\hline & Sertifikasi Guru & .364 & .082 & .361 & 4.449 & .000 \\
\hline
\end{tabular}

a. Dependent Variable: Kompetensi Guru

Berdasarkan hasil pengujian pada tabel di atas, pengaruh secara parsial variabel pengajaran berbasis teknologi informasi diperoleh nilai $t$ hitung $>t$ tabel atau $(3,978>1,980)$, dan ini diperkuat dengan signifikansi $0,000<0,05$. Dengan demikian hipotesis yang diajukan bahwa terdapat pengaruh yang signifikan antara pengajaran berbasis teknologi informasi terhadap kompetensi guru diterima.

Pengaruh secara parsial variabel sertifikasi guru diperoleh nilai thitung $>t$ tabel atau $(4,449$ $>1,980$ ), dan ini diperkuat dengan signifikansi 0,000 $<0,05$. Dengan demikian hipotesis yang diajukan bahwa terdapat pengaruh yang signifikan antara sertifikasi guru terhadap kompetensi guru diterima.

\section{c. Hasil Uji Koefisien Determinasi Secara Simultan}

Pengujian koefisien determinasi dimaksudkan untuk mengetahui besarnya persentase pengaruh dari variabel independen terhadap variabel dependen secara bersama-sama. Adapun hasil pengujian sebagai berikut:

Tabel 4. Hasil Pengujian Koefisien Determinasi Pengajaran berbasis teknologi informasi dan Sertifikasi guru secara bersama-sama Terhadap Kompetensi guru.

Model Summary

\begin{tabular}{lllll} 
Model & $\mathrm{R}$ & R Square & Adjusted R Square & Std. Error of the Estimate \\
\hline 1 & $.5 \mathrm{O}^{\mathrm{a}}$ & .252 & .239 & 4.89267 \\
\hline
\end{tabular}

a. Predictors: (Constant), Sertifikasi Guru, PBTI

Berdasarkan hasil pengujian pada tabel di atas, maka dapat diketahui bahwa kontribusi variabel-variabel bebas pada model 1 (satu) yaitu PBTI dan sertifikasi guru adalah sebesar 0,252 atau $25,2 \%$ sedangkan sisahnya 74,8\% adalah faktor-faktor lain yang tidak diteliti.

Resume hasil parth analisis sub-struktur 1 dapat digambarkan sebagai berikut:

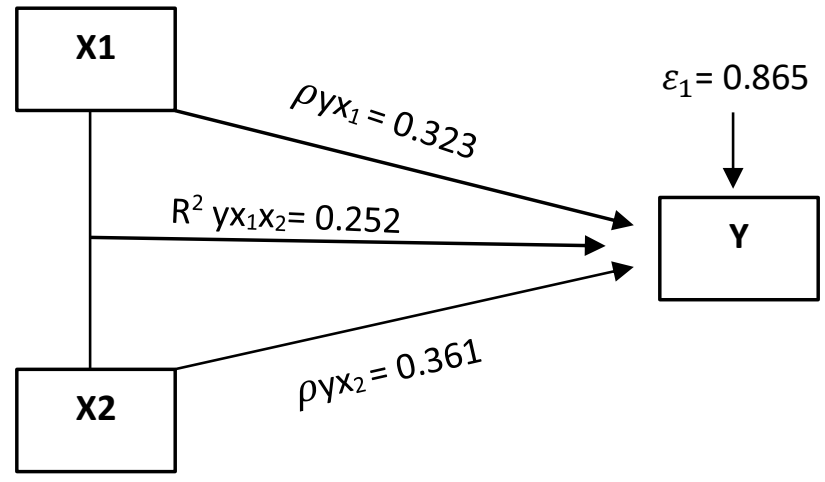

Gambar 1.

Diagram Jalur Hubungan Kausal Empiris X1, X2 Terhadap Y

\section{Analisis Jalur (Path Analisis) Sub-Struktur 2.}


Pada analisis ini dimaksudkan untuk mengetahui pengaruh variabel independen terhadap variabel dependen. Adapun hasil pengujian sebagai berikut:

\section{a. Uji Simultan (Uji F)}

Pada uji hipotesis ini dimaksudkan untuk mengetahui pengaruh secara simultan antara Pengajaran berbasis teknologi informasi dan sertifikasi guru terhadap kompetensi guru.. Adapun hasil pengujiannya sebagai berikut:

ANOVA $^{a}$

Tabel 5. Hasil Pengujian Hipotesis (Uji F)

\begin{tabular}{llllllll} 
Model & & Sum of Squares & df & Mean Square & F & Sig. \\
\hline 1 & Regression & 1018.286 & 3 & 339.429 & 20.238 & .ooo $^{\text {b }}$ \\
\cline { 2 - 7 } & Residual & 1895.245 & 113 & 16.772 & & \\
\cline { 2 - 4 } & Total & 2913.531 & 116 & & & \\
\hline
\end{tabular}

a. Dependent Variable: Kinerja Guru

b. Predictors: (Constant), Kompetensi Guru, PBTI, Sertifikasi Guru

Berdasarkan hasil pengujian pada tabel di atas, diperoleh nilai $\mathrm{F}$ hitung $>\mathrm{F}$ tabel atau $(20,238$ $>2,680$ ), dan ini diperkuat dengan signifikansi $0,000<0,05$. Dengan demikian hipotesis yang diajukan bahwa terdapat pengaruh yang signifikan antara pengajaran berbasis teknologi informasi, sertifikasi guru dan kompetensi guru terhadap kompetensi guru diterima.

b. Uji Parsial (Uji t)

Pada uji hipotesis ini dimaksudkan untuk mengetahui pengaruh secara parsial antara Pengajaran berbasis teknologi informasi, sertifikasi guru dan kompetensi guru terhadap kinerja guru. Adapun hasil pengujiannya sebagai berikut:

\begin{tabular}{|c|c|c|c|c|c|c|}
\hline \multicolumn{6}{|c|}{ Coefficients $^{\mathrm{a}}$} & \\
\hline \multicolumn{2}{|c|}{ Model } & $\mathrm{B}$ & Std. Error & $\begin{array}{l}\text { Standardized Coefficients } \\
\text { Beta }\end{array}$ & \multirow{2}{*}{$\frac{t}{2.470}$} & \multirow{2}{*}{$\frac{\text { Sig. }}{.015}$} \\
\hline 1 & (Constant) & 8.138 & 3.295 & & & \\
\hline & PBTI & .220 & .072 & .246 & 3.030 & .003 \\
\hline & Sertifikasi Guru & .213 & .074 & .237 & 2.870 & .005 \\
\hline & Kompetensi Guru & .294 & .078 & .329 & 3.747 & .000 \\
\hline
\end{tabular}

a. Dependent Variable: Kinerja Guru

Berdasarkan hasil pengujian pada tabel di atas, pengaruh secara parsial variabel pengajaran berbasis teknologi informasi diperoleh nilai $t$ hitung $>t$ tabel atau $(3,030>1,980)$, dan ini diperkuat dengan signifikansi $0,003<0,05$. Dengan demikian hipotesis yang diajukan bahwa terdapat pengaruh yang signifikan antara pengajaran berbasis teknologi informasi terhadap kinerja guru diterima.

Pengaruh secara parsial variabel sertifikasi guru diperoleh nilai thitung $>t$ tabel atau $(2,870$ $>1,980$ ), dan ini diperkuat dengan signifikansi 0,005 $<0,05$. Dengan demikian hipotesis yang diajukan bahwa terdapat pengaruh yang signifikan antara sertifikasi guru terhadap kinerja guru diterima.

Pengaruh secara parsial variabel kompetensi guru diperoleh nilai $\mathrm{t}$ hitung $>\mathrm{t}$ tabel atau $(3,747>1,980)$, dan ini diperkuat dengan signifikansi $0,005<0,05$. Dengan demikian hipotesis yang diajukan bahwa terdapat pengaruh yang signifikan antara kompetensi guru terhadap kinerja guru diterima.

\section{c. Hasil Uji Koefisien Determinasi Secara Simultan}

Pengujian koefisien determinasi dimaksudkan untuk mengetahui besarnya persentase pengaruh dari variabel independen terhadap variabel dependen secara bersama-sama. Adapun hasil pengujian sebagai berikut:

Tabel 7. Hasil Pengujian Koefisien Determinasi Pengajaran Berbasis Teknologi Informasi, Sertifikasi Guru

dan Kompetensi Guru secara bersama-sama Terhadap Kompetensi Guru.

Model Summary ${ }^{\mathrm{b}}$

\begin{tabular}{lllll} 
Model & R & R Square & Adjusted R Square & Std. Error of the Estimate \\
\hline
\end{tabular}

http://mahesainstitute.web.id/ojs2/index.php/jehss

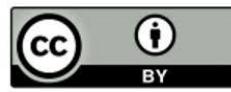




\begin{tabular}{lllll}
\hline 1 & $.591^{\mathrm{a}}$ & .350 & .332 & 4.09537 \\
\hline
\end{tabular}

a. Predictors: (Constant), Kompetensi Guru, PBTI, Sertifikasi Guru

b. Dependent Variable: Kinerja Guru

Berdasarkan hasil pengujian pada tabel di atas, maka dapat diketahui bahwa kontribusi variabel-variabel bebas pada model 2 (dua) yaitu PBTI, sertifikasi guru dan kompetensi guru adalah sebesar 0,350 atau 35,0\% sedangkan sisahnya 65,0\% adalah faktor-faktor lain yang tidak diteliti.

Resume hasil parth analisis sub-struktur 2 dapat digambarkan sebagai berikut:

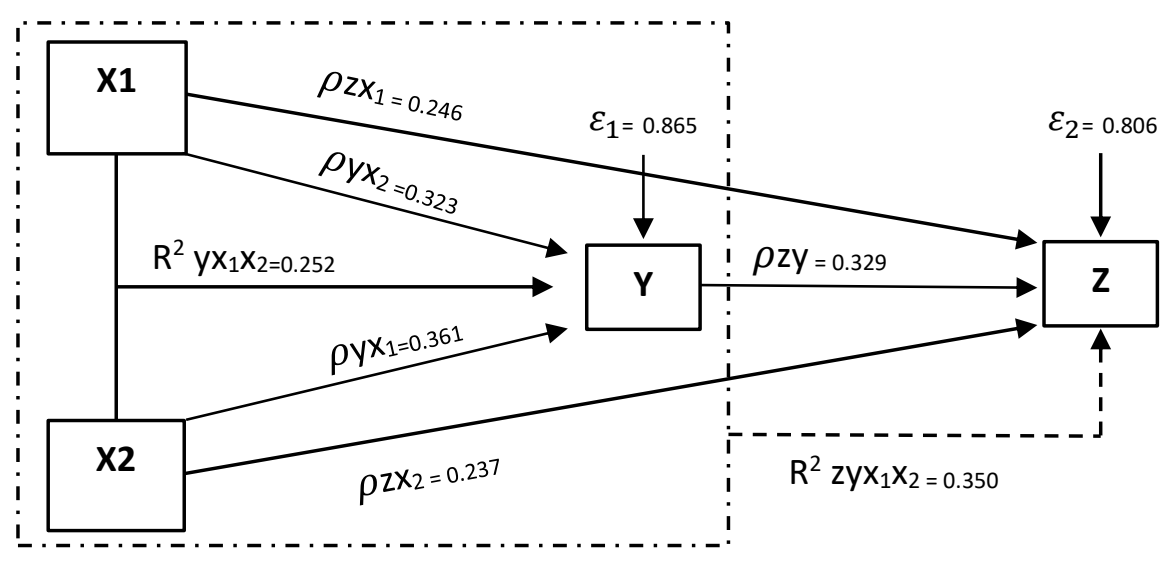

Gambar 2

Diagram Jalur Hubungan Kausal Empiris Variabel X1, X2, dan Y Terhadap Z

Pengajaran berbasis teknologi informasi berpengaruh signifikan terhadap kompetensi guru dengan pengujian hipotesis diperoleh nilai t hitung $>t$ tabel atau $(3,978>1,980)$. Dengan demikian hipotesis yang diajukan bahwa terdapat berpengaruh signifikan antara pengajaran berbasis teknologi informasi terhadap kompetensi guru diterima.

Sertifikasi guru berpengaruh signifikan terhadap kompetensi guru dengan pengujian hipotesis diperoleh nilai $t$ hitung $>\mathrm{t}$ tabel atau $(4,449>1,980)$. Dengan demikian hipotesis yang diajukan bahwa terdapat berpengaruh signifikan antara sertifikasi guru terhadap kompetensi guru diterima.

Pengajaran berbasis teknologi informasi dan sertifikasi guru berpengaruh signifikan terhadap kompetensi guru dengan nilai determinasi sebesar $25,2 \%$ sedangkan sisanya sebesar $74,8 \%$ dipengaruhi faktor lain. Pengujian hipotesis diperoleh nilai F hitung > F tabel atau $(19,213$ $>3,080$ ). Dengan demikian hipotesis yang diajukan bahwa terdapat berpengaruh signifikan secara simultan antara pengajaran berbasis teknologi informasi dan sertifikasi guru terhadap kompetensi guru diterima.

Pengajaran berbasis teknologi informasi berpengaruh signifikan terhadap kinerja guru dengan pengujian hipotesis diperoleh nilai t hitung $>t$ tabel atau $(3,030>1,980)$. Dengan demikian hipotesis yang diajukan bahwa terdapat berpengaruh signifikan antara pengajaran berbasis teknologi informasi terhadap kinerja guru diterima.

Sertifikasi guru berpengaruh signifikan terhadap kinerja guru dengan pengujian hipotesis diperoleh nilai $t$ hitung $>t$ tabel atau $(2,870>1,980)$. Dengan demikian hipotesis yang diajukan bahwa terdapat berpengaruh signifikan antara sertifikasi guru terhadap kinerja guru diterima

Sertifikasi guru berpengaruh signifikan terhadap kinerja guru dengan pengujian hipotesis diperoleh nilai $t$ hitung $>t$ tabel atau $(2,870>1,980)$. Dengan demikian hipotesis yang diajukan bahwa terdapat berpengaruh signifikan antara sertifikasi guru terhadap kinerja guru diterima

Kompetensi guru berpengaruh signifikan terhadap kinerja guru dengan pengujian hipotesis diperoleh nilai $t$ hitung $>t$ tabel atau $(3,747>1,980)$. Dengan demikian hipotesis yang diajukan bahwa terdapat berpengaruh signifikan antara kompetensi guru terhadap kinerja guru diterima 
Pengajaran berbasis teknologi informasi, sertifikasi guru dan kompetensi guru berpengaruh signifikan terhadap kinerja guru dengan nilai determinasi sebesar 35,0\% sedangkan sisanya sebesar 65,0\% dipengaruhi faktor lain. Pengujian hipotesis diperoleh nilai $\mathrm{F}$ hitung $>\mathrm{F}$ tabel atau $(20,238>2,680)$. Dengan demikian hipotesis yang diajukan bahwa terdapat berpengaruh signifikan secara simultan antara pengajaran berbasis teknologi informasi, sertifikasi guru dan kompetensi terhadap kinerja guru diterima.

\section{SIMPULAN}

Pengaruh PBTI (X1) terhadap kompetensi guru (Y). Uji statistik pada model struktur-1 didapat nilai $t_{\text {hitung }}>t_{\text {tabel }}(3.978>1.98)$ dan Sig $<0.05(0.000<0.05)$. Hasil ini mengartikan variabel PBTI secara parsial berpengaruh positif dan signifikan terhadap kompetensi guru. Pengaruh sertifikasi guru (X2) terhadap kompetensi guru (Y). Uji statistik pada model struktur-1 didapat nilai $t_{\text {hitung }}>t_{\text {tabel }}(4.449>1.98)$ dan Sig $<0.05(0.000<0.05)$. Hasil ini mengartikan variabel sertifikasi guru secara parsial berpengaruh positif dan signifikan terhadap kompetensi guru. Pengaruh PBTI (X1) dan sertifikasi guru (X2) secara simultan terhadap kompetensi guru (Y). Secara statistik pada model struktur-1 didapat nilai $F_{\text {hitung }}>F_{\text {tabel }}(19.213>3.08)$ dan Sig $<0.05$ $(0.000<0.05)$. Hasil tersebut mengartikan bahwa variabel PBTI dan sertifikasi guru secara simultan berpengaruh positif dan signifikan terhadap kompetensi guru

Pengaruh PBTI (X1) terhadap kinerja guru (Z). Secara statistik pada model struktur-2 didapat nilai $t_{\text {hitung }}>t_{\text {tabel }}(3.030>1.98)$ dan Sig $<0.05(0.003<0.05)$. Hasil tersebut mengartikan variabel PBTI secara parsial berpengaruh positif dan signifikan terhadap kinerja guru. Pengaruh sertifikasi guru (X2) terhadap kinerja guru (Z). Secara statistik pada model struktur-2 didapat nilai $t_{\text {hitung }}>t_{\text {tabel }}(2.870>1.98)$ dan Sig $<0.05(0.005<0.05)$. Hasil tersebut mengartikan variabel sertifikasi guru secara parsial berpengaruh positif dan signifikan terhadap kinerja guru. Pengaruh kompetensi guru (Y) terhadap kinerja guru (Z). Secara statistik pada model struktur-2 didapat nilai $t_{\text {hitung }}>t_{\text {tabel }}(3.747>1.98)$ dan Sig $<0.05(0.000<0.05)$. Hasil tersebut mengartikan variabel kompetensi guru secara parsial berpengaruh positif dan signifikan terhadap kinerja guru. Pengaruh PBTI (X1) sertifikasi guru (X2) dan kompetensi guru (Y) secara simultan terhadap kinerja guru (Z). Secara statistik pada model struktur-2 didapat nilai $F_{\text {hitung }}>F_{\text {tabel }}(20.238>2.68)$ dan Sig < $0.05(0.000<0.05)$. Hasil tersebut mengartikan bahwa variabel PBTI, sertifikasi guru dan kompetensi guru secara simultan berpengaruh positif dan signifikan terhadap kinerja guru.

\section{DAFTAR PUSTAKA}

Akbar, I.R., (2018) Analisis Kebijakan Kepala Sekolah Dalam Upaya Meningkatkan Kompetensi Guru (Study Kasus Pada Smk Muhammadiyah Parung). Masters thesis, Universitas Pamulang.

Cahyono, Y., Purwanto, A., Nurul Azizah, F., Wijoyo, H., Sihotang, M., \& Sugianto, A. (n.d.). Impact Of Service Quality,University Image And Students Satisfaction Towards Studentloyalty: Evidence From Indonesian Private Universities.

Fadilah, R., Parinduri, S.A., Syaimi, K.U., Suharyanto, A. (2020). Islamic Guidance and Counseling to Overcome The Study Difficulty of Junior High School Students in SMP IT Nurul Azizi Medan (Case Study of Students Experiencing Anxiety). International Journal of Psychosocial Rehabilitation

Gaol, M. L., Azhar A., (2013), Perbedaan Kompetensi Kepribadian dan Kompetensi Sosial Guru Sd Negeri yang Sudah Sertifikasi dan Yang Belum Sertifikasi, Analitika: 5 (2): 62-69

Hasmayani, B., Hotman S., (2012), Perbedaan Minat Sekolah dan Motivasi belajar Ditinjau dari Pola Asuh Orangtua, Analitika: 4 (1): 24-30

Indrawan, I., Wijoyo, H., Astuti, D., Sugianto, Selian, N., Aprianto, I., Wilyanita, N., Subhan, M., \& KZ, F. (2020). Manajemen Personalia Dan Kearsipan Sekolah (M. Latif (ed.); 1st ed.). Lakeisha.

Indrawan, I., Wijoyo, H., Suherman, \& Wiguna, I. M. A. (2020). Manajemen Pendidikan Karakter (M. Latif (ed.); PERTAMA). CV. Pena Persada.Juniarti, A.T. \& Sukartini, T. (2014). Analisis Kompetensi Lulusan melalui Kinerja Guru di SMPN Wilayah III Cirebon. Jurnal Trikonomika. Volume 13, No. 2, Thn. 2014, Hal. 145-152 ISSN 1411-514X (print) / ISSN 2355-7737 (online).http://journal.unpas.ac.id/index.php/trikonomika/article/download/610/345/.

Manurung, S.A.K., Lahmuddin L., (2010), Hubungan Self Regulated Learning dan Disiplin Terhadap Prestasi Belajar, Analitika: 2 (2): 76-87

656 http://mahesainstitute.web.id/ojs2/index.php/jehss


Milfayetty, S., (2009), Hubungan Kompetensi Kepribadian Guru Dan Reinforcement dengan Motivasi Belajar Siswa Di SMA Negeri 11 Medan, Analitika: 1 (1): 1-11

Mukhadis, A. \& Isnandar. (2012). Pengembangan Profesionalitas Berkelanjutan Guru Bersertifikat Pendidik Di SMK Rumpun Teknologi. Jurnal Teknologi Dan Kejuruan, Vol. 35, No. 1, Thn. 2012. http://journal.um.ac.id/index.php/teknologikejuruan/article/download/2977/632.

Simorangkir, N.R., Asih M., Azhar A., (2014) Kontribusi Komunikasi Persuasif Guru Terhadap Kepercayaan Diri Dan Motivasi Belajar, Analitika: 6 (2): 60

Siregar, N.I., Sri E., (2012) Hubungan Konsep Diri dan Kecerdasan Emosi dengan Motivasi Belajar, Analitika: 4 (1): 38-42.

Wijoyo, H., \& Indrawan, I. (2020). Model Pembelajaran Menyongsong New Era Normal Pada Lembaga PAUD Di Riau. JS (Jurnal Sekolah) Universitas Negeri Medan, 4(3), 205-212. https://doi.org/https://doi.org/10.24114/js.v4i3.18526

Wijoyo, H., Junita, A., Sunarsi, D., Setyawati Kristianti, L., Santamoko, R., Leo Handoko, A., Yonata, H., Haudi, Widiyanti, Ariyanto, A., Musnaini, \& Prasada, Suherman, D. (2020). Blended Learning Suatu Panduan (Vol. 1, Issue 1). 